Article

\title{
Towards a Shared Understanding of the Concept of Heritage in the European Context
}

\author{
Luigi Petti ${ }^{1}$, Claudia Trillo ${ }^{2} \mathbb{D}$ and Busisiwe Chikomborero Ncube Makore ${ }^{2, *(D)}$ \\ 1 Department of Civil Engineering, University of Salerno, 132, 84084 Fisciano SA, Italy \\ 2 School of the Built Environment, Salford University, Salford M5 4WT, UK \\ * Correspondence: B.C.Makore@salford.ac.uk
}

Received: 1 July 2019; Accepted: 21 August 2019; Published: 30 August 2019

check for updates

\begin{abstract}
The purpose of this paper is to develop an understanding of commonalities and differences in the concept of cultural heritage in Europe. This was achieved through a comprehensive academic and non-academic literature review focused on different definitions and conceptualisations related to cultural heritage internationally and in the European context. This is complemented with a comparative study in three European countries. This paper frames cultural heritage using the foundation set up by the United Nations Educational, Scientific and Cultural Organisation (UNESCO). It further discusses the European actors involved in defining heritage today. Finally, it focuses on three European countries and verifies that they share an understanding of cultural heritage including classifications, categorisation and heritage values. Findings from the overall study show how the definition of cultural heritage across Europe is reasonably homogeneous, and this is confirmed by the analysis of the three chosen test case studies. This finding is relevant to policy makers as it allows the support of potential common frameworks for heritage management at the European level, including risk management and risk reduction common methodologies. Further studies will shed light on the implementation issues which may arise from the creation of a common European framework for cultural heritage management, with emphasis on risk management and risk reduction of cultural heritage.
\end{abstract}

Keywords: cultural heritage; Europe heritage; classification; risk management

\section{Introduction}

Conceptualising cultural heritage globally and in Europe has become more multifaceted and sophisticated throughout the years, with the concept of heritage holding multiple meanings, depending on different sets of values [1-10]. Despite the complexity of the concept, it is still possible to identify similarities in the various approaches to heritage protection across Europe. The purpose of this study is to understand whether a common approach to the protection and safeguarding of European heritage can be identified, allowing the creation of shared methodologies to manage risks challenging heritage. Indeed, this study is part of a wider effort to develop a novel methodology for risk management and heritage, financed by the Italian Ministry for Education and Research [11]. The first step is to check if the current European context enables the creation of a common platform based on a shared definition of heritage. Once such a platform is ready, it would then be possible to move on and build a risk management strategy, based on a shared assumption about what assets need to be protected and which level of protection they would require.

This paper explores the progressive evolution of the concept of cultural heritage within Europe aiming to arrive at a more comprehensive understanding of the term within the different European contexts. The elaboration of concepts discussed in this paper use documents and publications at an international and state level. Acknowledging the varied complex definitions of Europe $[4,6,9]$ 
and taking into consideration the policy discourse central to this paper, Europe is defined here as membership to the European Union, although this is still acknowledged as a variable criterion for the cases discussed here. This paper is divided into four broad sections. Section 1 is the introduction followed by Section 2, a discussion on the concept of heritage through a main actor of developing a legislative framework, the United Nations Educational, Scientific and Cultural Organisation (UNESCO). Section 3 brings to attention the changing nature of the concept and definition of heritage within the European context through policy and scholarly discourse. This is followed by Section 4, which focuses on three European countries (Italy, England and Spain) to identify commonalities and differences in the respective legislative framework on understanding cultural heritage including classifications, categories and heritage values. Section 5 is the discussion and concludes in Section 6. It is anticipated that it is possible to identify a European common approach to heritage protection, suitable to support the construction of a shared methodology for risk management and heritage.

\section{The Conceptualisation of Cultural Heritage: The International Framework}

The aim of this section is to discuss the scope and nature of the concept of heritage in Europe, by exploring the official characterisation and construction of "European heritage" through UNESCO as a main vehicle. The preeminent role of UNESCO provides an internationally accepted operational definition of the term "heritage" through its directives, charters and international resolutions introduced over the last few decades. In the aftermath of the Second World War, the mobilisation of international cooperation in heritage conservation was channelled through UNESCO, initially to respect cultural property in the event of armed conflict $[7,8,12]$. It is within this context that UNESCO began its significant contributions to the adoption of a series of international conventions, recommendations and declarations that have led to the development of general international law. Marked by the first formal introduction of the expression of "cultural property", a direct reaction to the destruction of heritage in the Second World War was used in the Convention for the Protection of Cultural Property in the Event of Armed Conflict (The Hague, 14 May 1954) [13]. The preservation, collection and valorisation of cultural and natural heritage in view of the magnitude and gravity of the new dangers threatening them is the essence of the Preamble to the 1972 World Heritage Convention. This Convention is considered one of the most forward-looking conventions $[12,14,15]$. The World Heritage Convention reconciles previous definitions of cultural heritage and presents the definition as three categories: (1) monuments, (2) groups of buildings and (3) sites. After adopting the 1972 Convention, UNESCO drew up the World Heritage List including outstanding heritage in need of protection. Almost half of the sites are situated in Europe, with Italy heading the list followed by France, Germany and Spain, which share second place [16]. The list and Convention have been extensively criticised for proliferating the universal significance of European history and culture $[2,3,15,17]$. This is discussed further in the following section.

In 1992, the ICOMOS was assigned in an advisory role to implement the World Heritage Convention. The ICOMOS was established in 1965 by a group of primarily European architectural conservation experts $[18,19]$ creating guidelines for introducing contemporary buildings into ancient sites. By the turn of the millennium, UNESCO had widened the concept of cultural heritage to include cultural landscapes, canals and routes, as well as modern, rural and industrial architecture [20]—efforts which have been accepted and committed to in most cases by all three countries, Italy, England and Spain (Figure 1). As a result, UNESCO continued to place increasing scrutiny on the immaterial and material representations of heritage. This eventually led to a formal acknowledgment of the deeply rooted interdependence between the intangible and the tangible heritage through the 2003 Convention for the Safeguarding of the Intangible Cultural Heritage. Both Italy and Spain have signed their commitment towards adhering to this Convention. However, England has yet to do this (Figure 1). The intertwined nature of cultural heritage as a tangible outcome of intangible complex societal processes has been recognised by the international normative framework on the 27 September 2016 by the International Criminal Court, with the Mahdi's conviction (9 years), who helped to destroy shrines in 
Timbuktu. This milestone in the international law clarifies that the deliberate destruction of heritage has become a weapon of war, part of a broader strategy of cultural cleansing that includes murder and persecution of people in the short term, and the annihilation of identities and destruction of social fabric in the longer term.

\begin{tabular}{|c|c|c|c|}
\hline & Italy & England & Spain \\
\hline \multicolumn{4}{|c|}{ UNESCO Ratification Status } \\
\hline World Heritage Convention of 1972 & $23 / 06 / 1978$ & 29/05/1984 & $04 / 05 / 1982$ \\
\hline $\begin{array}{c}\text { Convention for the Safeguarding of the Intangible } \\
\text { Heritage of } 2003\end{array}$ & $30 / 10 / 2007$ & None & $25 / 10 / 2006$ \\
\hline \multicolumn{4}{|c|}{ Council of Europe Ratification Status } \\
\hline $\begin{array}{c}\text { Granada Convention for the Protection of the } \\
\text { Architectural Heritage of } 1985\end{array}$ & 05/04/2006 & 13/11/1987 & 27/04/1989 \\
\hline $\begin{array}{l}\text { Valletta Convention for the Protection of the } \\
\text { Archaeological Heritage (revised) of } 1992\end{array}$ & $05 / 04 / 2006$ & $19 / 09 / 2000$ & $10 / 01 / 2011$ \\
\hline Florence European Landscape Convention of 2000 & $05 / 04 / 2006$ & $11 / 2006$ & $11 / 26 / 2007$ \\
\hline
\end{tabular}

Figure 1. Comparison of international and European ratification status.

\section{The Changing Nature of Cultural Heritage in Europe}

In the case of Europe, key actors such as the European Union (EU) and the Council of Europe (CoE) have debated the meaning and scope of cultural heritage throughout the 1960s, 1970s and 1980s and into the twenty-first century $[10,12,16,19]$. European experts have played a leading role in developing international conservation standards and concepts concerning heritage [20]. They have participated at some point in the emergence of an EU discourse connecting European culture, values and identity without necessarily sharing the same goals $[6,12,17]$.

During World War Two, much cultural heritage was destroyed, triggering legislative actions to respond to the perceived threat. The $\mathrm{CoE}$ was the first post-war international organisation to use the term of cultural heritage in an official document introduced in the 1954 European Cultural Convention (Council of Europe Treaty Series No. 018). The concept of cultural heritage is broadened, introduced in three main dimensions: material (artefacts, monuments), intangible (language, history) and political (expression of political values and principles) [12]. The mention of intangible qualities of heritage at this time was different from the materialistic focus of UNESCO through the 1954 Hague Convention as mentioned in the section above. The International Charter of Venice (1964) expanded on the concept of conservation, giving emphasis to the need to have an active conservation that has a socially useful purpose [20]. This approach to cultural heritage inspired the development of resolutions by the European Parliament meant to give substance to a European identity beyond universal principles of democracy and human rights [12], consequently characterising the late nineteenth-century Europe with variants of nationalism and dynastic rule [1]. Numerous CoE heritage charters, conventions and recommendations were introduced to encourage the protection, at national level, of the cultural and natural heritage including the (1985) Convention for the Protection of the Architectural Heritage of Europe, known as the Granada Convention. The identification of cultural heritage to be protected and inventoried is further recognised in European regional heritage norms, such as the Council of Europe's (1992) Valletta European convention on the protection of the archaeological heritage. At this time, the Treaty of Maastricht was entered into force in 1993 by the European Union as a recognition of culture and cultural activities at a European level. The article calls EU members to respect their national diversity whilst foregrounding common cultural heritage. The use of valorisation is reflected in the Faro Convention on the Value of Cultural Heritage for Society of 2011 and the ICOMOS Burra Charter (1982), which proposes to protect the conservation of the cultural significance of a site, due to its aesthetic, historic, scientific or social value. This increasing policy discourse on strengthening European citizens' sense of belonging to the Union is often questioned by academics about its added value to 
local and community heritage. Delanty [6] argues that there is no underlying European self, but rather, European heritage is an endless reinterpretation of its own past. A recent manual by ICOMOS [21] under the mandate of the European Commission and in the framework of the flagship EU Initiative of the European Year of Cultural Heritage 2018 argues for a revised, modernised and integrated approach to heritage that responds to a changing context and new developments (p. 23) as advocated by the Faro Convention. This is with the aim to raise the threshold of desired quality on planning and implementing interventions on cultural heritage, thereby acknowledging notions of multidimensionality, inclusivity and diversity as key perspectives into defining future actions on EU cultural heritage. Although the discourse and motto of the EU "United in diversity" is championed, achieving this delicate balance between "unity" (common society and union) and "diversity" (pluralism and multiplicity) is still perceived as a significant challenge in reality. Aligned with this view is an increasing emerging policy discourse foregrounding effective dialogue between stakeholders (citizens, the public and private sector, voluntary, politicians and heritage professionals) and multiple interpretations and values. This context gives way to a sharing of heritage that can also be created through what Macdonald (2013) describes as "social memory" and "collective memory" (p. 15).

To establish this notion of common heritage, a plethora of funding instruments were introduced with a focus on promoting the European dimension and narrative to sites. An example of this is the European Heritage Label, created as a European response to UNESCO's World heritage list discussed in the section above. Other actions including the City of Culture launched in 1985 and the European Year of Cultural Heritage 2018 endeavour to allow EU citizens to gain a broad understanding of their cultural heritage in all its aspects, democratically share responsibility for it, celebrate it and benefit from the creation it inspires [16]. However, despite the many benefits of these top-down initiatives, they can be problematised [9]. Smith's [2] argument of heritage as a form of discourse assists in illuminating these challenges that are associated with official representations (authorised heritage discourse, or AHD). She explains that the authoritarian type of heritage conceptualisation has limited purchase for national groups as it is often interconnected with power relations based on Western national and elite class experiences. These powers reinforce "ideas of innate cultural value tied to time depth, monumentality, expert knowledge and aesthetics" [2: 299], a perspective that can be counter to the interests and desires of non-elite groups, although this consequently reinforces the division within European nationals and between European culture and the rest of the world. A counter discourse of singular European culture and identity is reflected in views of European culture and identity through EU-funded heritage-related research projects through the current Horizon 2020 research programme [22] as part of the European Year of Cultural Heritage. The projects are driven by the need for an understanding of Europe cultural heritage as a driver for sustainable growth and Understanding Europe-promoting the European public and cultural space [23]. An example of this is the Horizon 2020 funded project, "Critical heritages: performing and representing identities in Europe (CoHERE)" 2016-2019. The project explores existing heritage practices and discourses in Europe through heritage representations and performances that connect to ideas of place, history, tradition and belonging. The findings recommend the establishing of a scholarly discourse that promotes cross-border and transnational initiatives that stress interacting and plural heritages $[9,10]$. In similar vein, the project "CulturalBase. Social Platform on Cultural Heritage and European Identities" 2015-2017 argues that the transnationalising of heritage can promote heritage as a "right" to be involved in representing one's own culture. This perspective can be a beneficial counter to the expert-led and technical bureaucratic idea of heritage that tends to dominate official heritage management [17]. This paper therefore acknowledges that future findings from Horizon 2020 funded projects will continue to fill gaps of knowledge on European cultural heritage and provide depth and breadth in the conceptualisation of a common European heritage. Such investment in cultural heritage research activity also expands the scope by establishing links between cultural heritage and diverse aspects of contemporary life, such as urban policy and governance and sustainability. 
The following section discusses the nature and related definitions and classification of cultural heritage in four selected countries, with the purpose to verify the consistency between what has emerged from this section and the respective national framework.

\section{Establishing the Scope of Cultural Heritage in Different European Contexts}

The previous section showed how both in the international and in the European context, the intangible component of cultural heritage has been fully acknowledged as an independent category, thus leading to listing some new categories of assets previously not considered (i.e., oral traditions, festivals, etc.), as well as re-casted as an inseparable component of any of the categories previously classified and listed as cultural tangible heritage. The changing nature of the concept of heritage evolved almost in parallel internationally and in the European contexts, contributed by the international debate nurtured by international networks and institutions, which ensured consistency of approaches. This section builds on and moves forward this initial finding, by testing it against three selected case studies: Italy, England and Spain. The three case studies WERE chosen because all countries have a well-established tradition on cultural heritage conservation and are included in the top ten World Heritage Sites list. The three cases are not a representative sample of the European approach to heritage conservation. However, they are intended to be instrumental in facilitating a discussion and exploration on the complexity of the approaches to heritage conservation in Europe. The methodology for investigating the three case studies has been based on the analysis of international and local documents and literature, while the findings have been corroborated by feedback provided by local experts in the field of heritage conservation. It is anticipated that all the three cases confirm the initial finding, i.e., a reasonably common understanding of the concept of heritage at European level does exist.

\subsection{Cultural Heritage in the Context of Italy}

Italy has historical involvement in the protection of cultural heritage. Italian heritage has been at the centre of the debate on preservation, valorisation and heritage protection since the 1920s and after the Second World War. In fact, over half of all building activity is preservationist in nature [24]. The development of international discourse on heritage conservation was largely influenced by reflections and the development of theories on urban conservation and morphology in Italy's heritage [24-26]. Therefore, the developed charters and acts are inextricably mixed with the philosophies, such as the restoration theories of Viollet-le-Duc and Ruskin [27]. In terms of legislation relevant to the heritage preservation and conservation, it is important to first note that the Italian Constitution (Article 9) promotes cultural heritage and gives urban planning authority to individual regions [28]. Italy's legislation regarding cultural heritage is a decentralised system organised in three levels: national, regional and municipal [29], with active involvement of the local authorities in heritage work within a highly constrained and rigidly regulated national framework. Two main pieces of legislation were introduced in 1939 with the purpose to redefine cultural heritage. Firstly, the 1939 no 1089 "Tutela delle cose d'interesse Artistico o Storico" (Preservation of material assets of artistic or historical interest) code was known as the first organic legislation regulating the preservation of cultural heritage [24,29]. This code widened the range of heritage subject to protection, thereby including parks and villas, and the subsequent second legislation for the protection of landscapes was given in 1939 no 1497 "Protezione delle bellezze naturali" (Protection of natural beauty assets). Another classification of cultural heritage is introduced in the 1967 Franceschini Commission in groups which are still relatively effective: archaeological; historical; artistic; environmental; landscape; archival and book heritage [30].

In the post-war period, historical city centres became a dominant part of the general urban development agenda discussed in Town Planning and Social Housing journals and within the municipal councils [31]. The notion of a "historical centre" is introduced from a normative standpoint, straight after the Second World War, driven by the need to reconstruct and preserve cities. Researchers and planners such as Astengo and Cavallari Murat contributed to development of innovative planning 
instruments, encompassing the notion of protecting the wider historical city context [32]. There was an inclination to classify cultural heritage as a cluster of assets interdependent with one another (territories and environments) and part of a specific context, not just as a solitary building [26,30,31].

The 1999 Law no 490 "Testo unico delle disposizioni legislative in materia di beni culturali e ambientali" (The coordinated law text regulating cultural and environmental assets) was enacted to protect cultural heritage and display progression in the conceptualisation of cultural heritage [33]. Heritage was defined as "things of artistic and historic interest" in the 1939 law; however, the 1999 Law made up for this inadequacy by broadening the range of protected objects (including photographs with their negatives and relating to the history of science and scientific techniques). At the national level, the 2004 "Codice dei beni culturali e del paesaggio" (Code on cultural assets and landscape), also known as the "Urbani Code", collates all the legislation for cultural and natural heritage. In this legislation, the term "cultural assets" is used. It is defined as immovable and movable property presenting artistic, historical, archaeological, ethno-anthropological, archival and bibliographic interest as well as being rare and valuable [34]. This law does not offer different grades or levels of protection. Instead, there is one level of protection given to eligible objects. The protection of heritage is ensured by the Ministry of Heritage, which is articulated in a network of local offices centrally dependent on the national Minister. This ensures consistency in the protection of the heritage, which originates from the national Constitution. Regional governments are competent authorities for the activities aimed at the enhancement of the tangible heritage assets.

\subsection{Cultural Heritage in the Context of England}

The scope and definition of heritage in the UK has developed over the last few decades from a focus on monumentalism and prioritised grandeur, to one which normalises areas and buildings which, may be argued, have no aesthetic glory, such as industrial, post-war heritage and heritage landscapes [35-37]. Such wider versions of heritage have become embedded in recent planning policy and practice, becoming part of contemporary heritage discourse [2,35]. The 2018 National Planning Policy Framework (NPPF) defines a heritage asset as "A building, monument, site, place, area or landscape identified as having a degree of significance meriting consideration in planning decisions, because of its heritage interest" [38].

In the 19th Century, there was an increasing public interest in ancient monuments and buildings stimulated by the work of topographers and historians [39]. This rising discourse began initially as monument-centric, with the enactment of the Ancient Monuments Protection Act in 1882, passed to solely protect ancient monuments such as long barrows and stone circles [40]. This legislation was the first step towards the development of statutory classification of heritage known as "Listing" after the Second World War [37,41]. It provided protection of approximately 50 prehistoric areas [42] and appointed a single inspector of ancient monuments. The stage was therefore set for the birth of a modern system of heritage protection and classification [43]. The demolition of houses during the Second World War acted as a catalyst for more robust legislation [40], namely, the Ancient Monuments and Archaeological Areas Act 1979. This Act broadly defines monuments as buildings, structure, site or remains above or below the surface of the land, or any cave, excavation or other movable structure that is a matter of public interest [44].

By the mid-1980s, conservation planning in England had evolved into an established and robust system for protecting and classifying the built heritage of architectural or historical interest. It was based around a hierarchy of "listing" to grade relative significance at Grade I (buildings of exceptional importance), Grade II* (particularly important buildings of more than special interest) and Grade II (buildings of special interest). The primary legislation called the Town and Country (Listed Buildings and Conservation Areas) Planning Act 1990 imposes a duty on the Secretary of State to compile or approve a list or lists of buildings of special architectural or historic interest (listed buildings) as a guide to planning authorities when carrying out their planning functions [45]. The policy prescribes the statutory criteria that should be followed when assessing whether a building is of special architectural 
or historic interest and should be added to the list [46]. The statutory protection on the built heritage in England extends into gardens, parks and landscapes. The Buildings and Ancient Monuments Act 1953 gives authority for the compilation of "a register of gardens and other land situated in England and appearing to them to be of special historic interest" [47]. The register was established in 1983 under the National Heritage Act the Register, which is administered by Historic England. The classification for parks and gardens follows the same convention as for listed buildings in that a landscape can be listed at Grade I, Grade II* or Grade II depending on its relative national significance. Although this extension to the scope of protected heritage is progressive, there is still an emphasis on the physicality, such as structure, design style and materials [48]. Influenced by the growing discourse on the immaterial, heritage conservation in the UK has begun to appreciate the association of tangible forms with elements of immaterial, social and traditional significance and value [48], thus progressing from an exclusive way of seeing defined by the nation, expertise, tangibility and White middle and upper classes [49]. Although the UK has not ratified the 2003 Convention for the Safeguarding of the Intangible Cultural Heritage (Figure 1), comments made by the Department for Culture, Media and Sport suggested that the Government acknowledges "the contribution that the UK's oral traditions, social practices and festive events make to the country's cultural fabric and continues to encourage communities to celebrate these practices" [50].

\subsection{Cultural Heritage in the Context of Spain}

Spain has a relatively complex administrative structure for the preservation of cultural heritage [29,51], with multiple agents including the state government, regional government, autonomous communities, private and financial institutions and individual owners [52,53]. Heritage policy was brought to a halt during the years of Franco's power from 1939 to 1975 [54]. Accelerated urbanisation led to the degradation of Spanish cities and their architectural heritage $[55,56]$ with the replacement of historic quarters with new residential dwellings. During this time, Spain emerged as a state-driven heritage industry side-by-side with preservationist practices of monumentalism and the isolation of historical artefacts without considering their environments [54,57]. Therefore, the political change ending the Franco regime prompted increased support and initiative for heritage and its preservation [55]. An example of this is the text in Article 46 of the 1978 Constitution, which goes beyond conservation and promotes the "enrichment of the historical, cultural and artistic heritage" of Spain [58].

One of the first major reforms undertaken after a few years of the Socialist government is the Historical Heritage Act of 1985. This law put cultural policies and deteriorating historic and artistic heritage to the foreground of public attention [59]. A new wide-ranging definition of heritage is included in this Act (Article 15) detailing real estate and movable objects, documentary and bibliographic heritage, the archaeological sites and areas, as well as natural sites, gardens and parks which have artistic, historical or anthropological value [60]. By expanding on the concept of cultural heritage, which was traditionally centred on artistic monuments, the heritage law improved its social background by enabling any asset that is not declared officially to be considered as historical heritage [51]. Additionally, this piece of legislation was pioneering in heritage protection policy by gradually transferring responsibilities to the regional authorities and municipal councils, thereby decentralising the government, thus characterising Spain's institutional framework by its Autonomous Communities and the administrative territories into which it is divided [52,56]. However, these different administrative levels are often found to be self-serving and conflicting in an attempt to accrue mutually exclusive heritage jurisdiction [55]. Within these regions, there are certain standards concerning conservation, rehabilitation and the protection of historic heritage [29]. It is also worth noting that support is provided for maintenance, preservation and rehabilitation work through $1 \%$ of the State Administration budget that must be used to assist the historic heritage [52,57]. Town councils regulate matters according to Special Preservation Plans; however, there are reserve powers of control by the heritage administration. These special plans are of significance for the maintenance of 
the urban and architectural structure as well as the settings of historical sites [52,53,57,60]. Following these advances, from 1990, the Autonomous Communities began using these newly given powers to create their own laws for cultural heritage as well as a regional cultural identity [61].

To a certain extent, a common feature in these laws stemming from the 1985 Heritage Act is the classification of cultural assets into three main categories, immovable, movable and intangible as well as an additional category of special heritage (archaeological, ethnographic, documentary, bibliographic and even industrial) [51,60]. Another commonality is the establishment of three levels of protection, the first being the maximum, for Assets of Cultural Interest [51]. Focusing on immovable assets, this protection covers the most prominent cultural assets including monuments, historic gardens, historic ensembles, historic sites and archaeological areas [60], although almost all Autonomous Communities have expanded on these categories by including, for example, areas of ethnographic or ethnological interest, monumental complexes, paleontological areas and archaeological protection areas. The second level of protection is the intermediate (Inventoried or Catalogued), and the third is the minimum level which mainly consists of integrating assets of cultural heritage [51].

Changes in the field of cultural heritage such as the introduction of international conventions and new challenges in the protection of national heritage highlighted the need to modernise the 1985 Historical Heritage Act [57]. Heritage as a concept began increasingly being approached as an assemblage that includes material and immaterial forms: representations and aspirations, mortar and emotions, values and interpretations, symbols and narratives [61,62], therefore leading to work by the Ministry of Culture on a draft Act on Cultural Heritage in 2008. The conceptualisation of Spanish heritage was further broadened with the approval of the Act on Protection of Intangible Cultural Heritage in 2014, as well as new initiatives on integrating cultural assets into landscape development [51,53]. Although this is a step in the right direction, the continuous fragmentation of Spanish laws and the various initiatives make it difficult to integrate the protection of cultural heritage and promoting support for its protection and management.

\section{Discussion}

Findings from the analysis of the literature show how the policy definition of cultural heritage across Europe can be considered as reasonably homogeneous, and this is confirmed by the in-depth analysis of the three chosen testing case studies. The driver of such homogeneity can be identified in the consistent and continuous action of the international researchers and experts' community, through international governmental and nongovernmental institutions (e.g., UNESCO, ICOMOS), performed through charters, documents and brought at the local level through a constant advocacy process, which created the conditions for having such a common understanding at local level. Although the foundations of heritage are slightly different in each context [63], the current conceptualisations of heritage have emerged with a similar redefined narrative. As discussed in Section 2 of this paper, UNESCO has played a pivotal role in mobilising such a Eurocentric discourse that values the authenticity of original fabric and aesthetic qualities. It places European values as central to human history, engaging in what Smith [2] describes as "heritage making".

The assets considered as heritage by UNESCO are wide-ranging, including monuments, groups of buildings and areas and sites of outstanding universal value [14], and more recently including intangible assets. This evolution of the nature of the concept of cultural heritage is consistent in the European landscape. The main shift has been concerned with incorporating the larger sociocultural value as a dynamic process of co-creation of the cultural assets, beyond the static appreciation of the aesthetic value of the cultural heritage as such. Heritage is therefore considered as shaping processes of social inclusion [1,49]. This shift has been expressed with the incorporation of the intangible expressions of cultural heritage as autonomous ontological category of objects to protect, as well as with the expansion of the criteria underpinned to the recognition of value for the traditional categories such as monuments, parks and other tangible assets. The policy rhetoric of perceiving cultural heritage as a vector of dialogue, cooperation and mutual understanding is emphasised as a prime motivation for 
protecting heritage, although Meskell [64] argues that these utopian goals are mired by the promotion of competitive branding through the World Heritage sites and bureaucracy surrounding it [17]. These sociopolitical and economic agendas are reflected in the European pursuit of common identity and unity for all members $[65,66]$, promoting European values and community action in favour of bringing European citizens closer together [12]. At both levels, the hallmark of heritage industry is continuously redefined as the preservation of cultural heritage referring not just to its materiality, but also considering the wider potential allowing for multiple benefits.

The analysis of the three chosen case studies conducted in the previous sections allows the identification of commonalities across the three cases, confirming that the concept of heritage as elaborated and accepted at international and European level reflects the three chosen countries' framework and underpinned values. Figure 2 displays a comparative image of the scope of heritage assets in the three country contexts. The three countries have different forms of classifying cultural heritage. In all three county contexts, there is reference to movable and non-movable assets stemming from the UNESCO framework. There is less clarity to the embedded and interdependent nature of the intangible qualities within the conceptualisation of heritage. One can identify three main categories that are present in all contexts: monuments, historic ensembles and sites and landscape heritage, such as gardens and parks. The associated values mentioned in Table 1 include artistic, aesthetic and archaeological values but also different values that testify to the symbolic and civic qualities of each country.
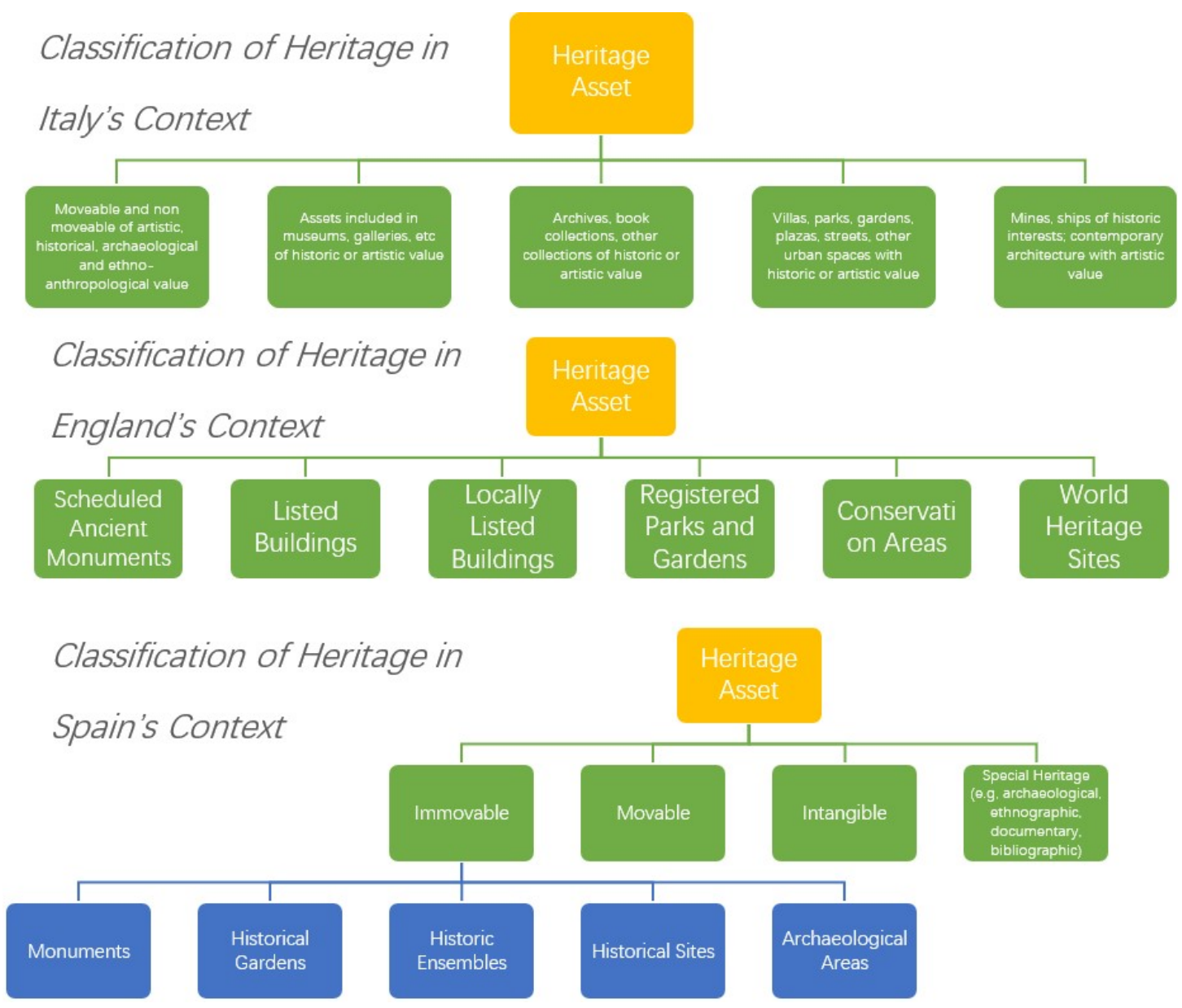

Figure 2. Classification of heritage in country contexts. 
Table 1. Comparative analysis of the heritage concept in England, Italy and Spain.

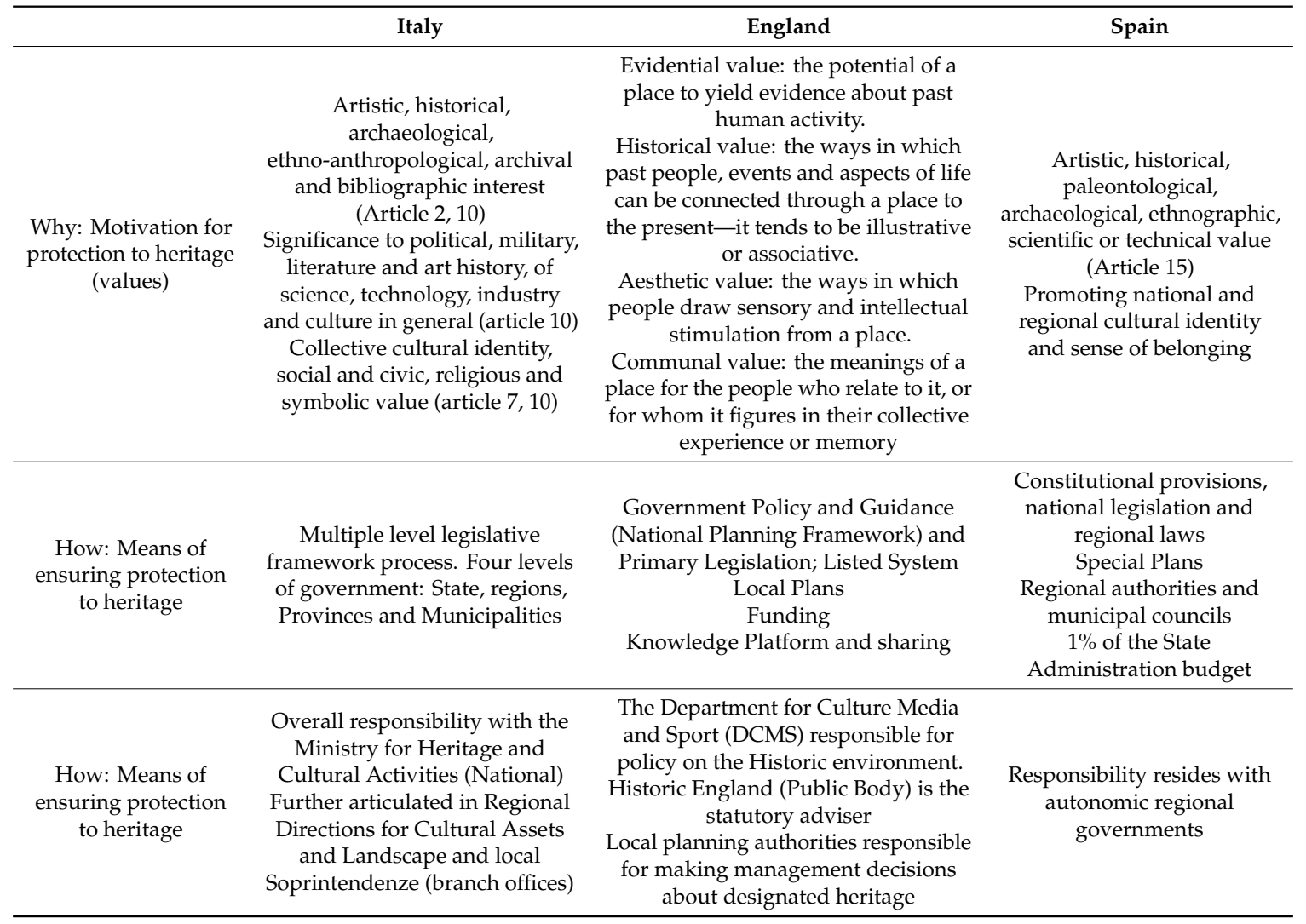

With regard to the measures of ensuring protection to heritage, each country has different approaches (Table 1). In England, there is a strong focus on national legislation, particularly through planning policies. This is coordinated with local councils to protect heritage through the listing process described in Section 4.2. The public body, Historic England is tasked with protecting the historical environment of England by preserving and listing historic buildings, ancient monuments and advising central and local government. In Italy, the coordination of protection is a bit more complex, with balance between the Ministry and regional entities with procedures allowing for database and knowledge sharing through municipal plans. Some efforts are made to support the municipalities with tools to allow them to apply distinct measures and levels of intervention [29]. By contrast, Spain's autonomous communities have their own process of protection with minimal national coordination, where each region adapts the national law according to the characteristics of their own heritage.

\section{Conclusions}

In conclusion, how the concept of heritage can be considered as reasonable homogeneous at European policy level and intertwined with the international charters and documents has been discussed. Indeed, the contribution of Europeans to international institutions (UNESCO, ICOMOS) in the definition of concepts and approaches has been more than significant; hence, such an alignment was expected. The three case studies chosen for testing this initial finding confirmed that at national level, assets, values and instruments also reflect the international and European framework. This finding is relevant to policy makers, since it allows supporting potential common frameworks for cultural heritage management at European level, including risk management and risk reduction policies. As anticipated in the introductory section, this paper represents the first step of a wider research aimed at creating a common framework for the protection of European heritage. This will be achieved by identifying a homogeneous system of classification of heritage and associated values first, then by evaluating the exposure to the risk and associated protection strategies. Findings from this paper 
were essential to set the basis for creating a potential common platform for classification. Conversely, despite this consistent policy discourse, there are limitations in knowledge about the possibility of integrating and recognising plural views of heritage, perhaps more evident at the community level within a common European framework, and what this means for risk assessment. Additionally, further interrogation is needed into the power relations and how decisions can be made about what should be kept and what not. Future studies will shed light on the implementation issues which may arise from the creation of a common European framework for cultural heritage management, with emphasis on risk management and risk reduction of cultural heritage.

Author Contributions: This article reflects the outcome of a joined discussion among the three authors, whoshare the conceptualisation and the research methodology. L.P. is the project supervisor, manager and he is responsible for the funding. C.T. is the project external adviser, she drafted the concept and reviewed the draft. B.C.N.M. was responsible for writing and editing the article.

Funding: This research is financed by the PRIN program-Research Projects of National Interest, Italian Ministry for University and Research, n. 2015EAM9S5, Project name "Protecting the Cultural Heritage from water-soil interaction related threats".

Conflicts of Interest: The authors declare no conflict of interest. The funders had no role in the design of the study; in the collection, analyses, or interpretation of data; in the writing of the manuscript, or in the decision to publish the results.

\section{References}

1. Graham, B.; Ashworth, G.; Tunbridge, J. A Geography of Heritage: Power, Culture and Economy, 1st ed.; Routledge: New York, NY, USA, 2000. [CrossRef]

2. Smith, L. Uses of Heritage; Routledge: London, UK, 2006; p. 368. [CrossRef]

3. Lowenthal, D. The Heritage Crusade and the Spoils of History; Cambridge University Press: Cambridge, UK, 1998. [CrossRef]

4. Macdonald, S. Memorylands: Heritage and Identity in Europe Today; Routledge: London, UK, 2013.

5. Delanty, G. Europe and Asia Beyond East and West; Routledge: London, UK, 2006. [CrossRef]

6. Delanty, G. The European Heritage from a Critical Cosmopolitan Perspective. LSE 'Europe in Question' Discussion Paper Series. 2010. Available online: http://www.lse.ac.uk/european-institute/Assets/Documents/ LEQS-Discussion-Papers/LEQSPaper19b.pdf (accessed on 1 August 2019).

7. Yahaya, A. The Scope and Definitions of Heritage: From Tangible to Intangible. Int. J. Herit. Stud. 2006, 12, 292-300.

8. Vecco, M. A definition of cultural heritage: From the tangible to the intangible. J. Cult. Herit. 2010, 11, 321-324. [CrossRef]

9. Whitehead, C.; Bozoğlu, G. Heritage and Memory in Europe: A Review of Key Concepts and Frameworks for CoHERE; Performing and Representing Identities in Europe Work Package 1 Work in Progress; Critical Heritages (CoHERE): Newcastle, UK, 2017. Available online: https://eprint.ncl.ac.uk/file_store/production/ 239678/CD7C34A7-DEDC-4BAA-9168-3FC71006C70A.pdf (accessed on 10 August 2019).

10. Whitehead, C.; Eckersley, S.; Zito, A. European Policy Brief: Productions and Omissions of European Heritage; CoHERE, Newcastle University: Newcastle, UK, 2019.

11. PRIN. Protecting the Cultural Heritage from Water-Soil Interaction Related Threats, in Research Projects of National Interest; Italian Ministry for University and Research: Salerno, Italy, 2015.

12. Calligaro, O. From 'European Cultural Heritage' to 'Cultural Diversity'? The Changing Core Values of European Cultural Policy; Cairn.info pour L'Harmattan: Paris, France, 2014; pp. 60-85. Available online: https: //www.cairn.info/revue-politique-europeenne-2014-3-page-60.htm (accessed on 1 January 2019).

13. UNESCO. Convention for the Protection of Cultural Property in the Event of Armed Conflict with Regulations for the Execution of the Convention; United Nations Educational Scientific and Cultural Organisation: The Hague, The Netherlands, 1954. Available online: http://www.unesco.org/new/en/culture/themes/armed-conflictand-heritage/convention-and-protocols/1954-hague-convention/ (accessed on 1 November 2018).

14. UNESCO. Convention Concerning the Protection of the World Cultural and Natural Heritage; United Nations Educational Scientific and Cultural Organization (UNESCO): Paris, France, 1972. Available online: http://whc.unesco.org/en/conventiontext/ (accessed on 1 November 2018). 
15. Labadi, S. UNESCO, Cultural Heritage, and Outstanding Universal Value Value-based Analyses of the World Heritage and Intangible Cultural Heritage Conventions; AltaMiraPress: New York, NY, USA, 2013.

16. Pasikowska-Schnass, M. Cultural Heritage in EU Policies; European Union, European Parliamentary Research Service: Brussels, Belgium, 2018. Available online: http://www.europarl.europa.eu/RegData/etudes/BRIE/ 2018/621876/EPRS_BRI(2018)621876_EN.pdf (accessed on 1 February 2019).

17. Chalcraft, J.; Delanty, G. Can Heritage Be Transnationalised? The Implications of Transnationalism for Memory and Heritage in Europe and Beyond; AXIS 1. CULTURAL MEMORY TF1. Memory and Heritage; University of Sussex: Brighton, UK, 2015. Available online: https://culturalbase.eu/documents/1.\%20CHALCRAFT\%20\& \%20DELANTY.\%20Can\%20Heritage\%20be\%20Transnationalised.pdf (accessed on 10 August 2019).

18. Gfeller, A.L.E. Negotiating the meaning of global heritage: 'Cultural landscapes' in the UNESCO World Heritage Convention, 1972-1992. J. Glob. Hist. 2013, 8, 483-503. [CrossRef]

19. Zito, A.R.; Eckersley, S.; Turner, S. The Instruments of European heritage. In Dimensions of Heritage and Memory: Multiple Europes and the Politics of Crisis; Whitehead, C., Eckersley, S., Eds.; Routledge: Abingdon, UK, 2019.

20. Soldano, S.; Borlizzi, P.; Valle, M. Report on Current State-of-Art of Use and Re-Use of Medieval Ruins; European Union Interreg Central Europe: Brussels, Belgium, 2017. Available online: https://www.interregcentral.eu/Content.Node/D.T2.1.1---Report-on-the-current-state-of-art-on-contempo-1-.pdf (accessed on 1 November 2018).

21. ICOMOS International. European Quality Principles for EU-Funded Interventions with Potential Impact upon Cultural Heritage; ICOMOS International: Paris, France, 2019. Available online: http://openarchive.icomos. org/2083/1/European_Quality_Principles_2019_EN.PDF (accessed on 1 August 2019).

22. European Commission, Communication from the Commission to the European Parliament, the Council, the European Economic and Social Committee and the Committee of the regions. Towards an Integrated Approach to Cultural Heritage for Europe; European Commission: Brussels, Belgium, 2014. Available online: https://eur-lex.europa.eu/legal-content/EN/TXT/?qid=1412240757164\&uri=CELEX:52014DC0477 (accessed on 1 March 2019).

23. European Commission. Mapping of Cultural Heritage Actions in European Union Policies, Programmes and Activities; European Commission: Brussels, Belgium: 2017. Available online: http://ec.europa.eu/assets/eac/ culture/library/reports/2014-heritage-mapping_en.pdf (accessed on 1 March 2019).

24. Jet, A.C. Domestic, supranational and international historic preservation legislation: Does it protect our cultural heritage or restrict development? Exploring its' impact on ancient roman monuments. Ga. J. Int. Comp. Law 2003, 31, 651-678.

25. Micelli, E.; Pellegrini, P. Wasting heritage. The slow abandonment of the Italian Historic Centers. J. Cult. Herit. 2018, 31, 180-188. [CrossRef]

26. Piccinato, G. Historic Centres under Pressure. Lights Andshadows from the Italian Experience; AESOP Congress: Vienna, Austria, 2005. Available online: https://www.academia.edu/4482139/HISTORIC_CENTRES_ UNDER_PRESSURE._LIGHTS_AND_SHADOWS_FROM_THE_ITALIAN_EXPERIENCE (accessed on 1 November 2018).

27. Dainotto, R. The Gubbio Papers: Historic Centers in the Age of the Economic Miracle. J. Mod. Ital. Stud. 2003, 8, 67-83. [CrossRef]

28. Senato della Repubblica. The Constitution of the Italian Republic; Senato della Repubblica: Rome, Italy, 1947. Available online: https://www.senato.it/documenti/repository/istituzione/costituzione_inglese.pdf (accessed on 1 January 2019).

29. Ornelas, C.; Guedes, J.M.; Breda-Vázquez, I. Cultural built heritage and intervention criteria: A systematic analysis of building codes and legislation of Southern European countries. J. Cult. Herit. 2016, 20, 725-732. [CrossRef]

30. Bosna, C. The Didactic-Educational Dimension of Our Territory, in International Conference RCIC'17 Redefining Community in Intercultural Context; The Italian Constitution and the Cultural Heritage: Bari, Italy, 2017.

31. Piccinato, G. Words and History: Controversies on Urban Heritage in Italy, in Culture, Urbanism and Planning; Monclus, J., Guardia, M., Eds.; Routledge: New York, NY, USA, 2006.

32. Bravo, L.; Mingucci, R. Centri Storici. Evoluzione Normativa e Modelli di Rappresentazione; Disegnarecon: Bologna, Italy, 2008. 
33. Gianighian, G. Italy, in Policy and Law in Heritage Conservation; Pickard, R., Ed.; Routledge: New York, NY, USA, 2001.

34. Il Presidente della Repubblica. Decreto Legislativo 22 Gennaio 2004, No. 42, Codice dei beni Culturali edel Paesaggio, ai Sensi Dell'articolo 10 Della Legge 6 Luglio 2002, No. 137; La Presidenza del Consiglio dei Ministri: Rome, Italy, 2004.

35. Ludwig, C. From bricks and mortar to social heritage: Planning space for diversities in the AHD. Int. J. Herit. Stud. 2016, 22, 811-827. [CrossRef]

36. Pendlebury, J. Conservation values, the authorised heritage discourse and the conservation-planning assemblage. Int. J. Herit. Stud. 2013, 19, 709-727. [CrossRef]

37. English Heritage Conservation Principles. Policies and Guidance: For the Sustainable Management of the Historic Environment; Historic England: London, UK, 2008.

38. Ministry of Housing Communities and Local Government. National Planning Policy Framework; Secretary of State for Ministry of Housing, Communities and Local Government by Command of Her Majesty: London, UK, 2018.

39. Harvey, D.C. Heritage Pasts and Heritage Presents: Temporality, meaning and the scope of heritage studies. Int. J. Herit. Stud. 2001, 7, 319-338. [CrossRef]

40. Larkham, P. The place of urban conservation in the UK reconstruction plans of 1942-1952. Plan. Perspect. 2003, 18, 295-324. [CrossRef]

41. Historic England about the List. 2019. Available online: https://historicengland.org.uk/listing/the-list/ (accessed on 1 March 2019).

42. UK Parliament Preserving Historic Sites and Buildings. 2019. Available online: https://www.parliament. uk/about/living-heritage/transformingsociety/towncountry/landscape/overview/historicsites/ (accessed on 1 March 2019).

43. Fry, S. A History of the National Heritage Collection Volume Two: 1900-1913; English Heritage: London, UK, 2014.

44. UK Government. Ancient Monuments and Archaeological Areas Act 1979; UK Government: London, UK, 1979. Available online: http://www.legislation.gov.uk/ukpga/1979/46/pdfs/ukpga_19790046_en.pdf (accessed on 1 November 2018).

45. UK Government. Planning (Listed Buildings and Conservation Areas) Act 1990; UK Government: London, UK, 1990. Available online: https://www.legislation.gov.uk/ukpga/1990/9/pdfs/ukpga_19900009_en.pdf (accessed on 1 November 2018).

46. Department for Digital Culture Media \& Sport. Principles of Selection for Listed Buildings; Department for Digital, Culture, Media \& Sport, UK Government: London, UK, 2018.

47. UK Government. Historic Buildings and Ancient Monuments Act; UK Government: London, UK, 1953. Available online: https://assets.publishing.service.gov.uk/government/uploads/system/uploads/attachment_ data/file/757054/Revised_Principles_of_Selection_2018.pdf (accessed on 1 March 2019).

48. Turnpenny, M. Cultural Heritage, an Ill-defined Concept? A Call Joined-Up Policy. Int. J. Herit. Stud. 2004, 10, 295-307. [CrossRef]

49. Waterton, E. Sights of sites: Picturing heritage, power and exclusion. J. Herit. Tour. 2009, 4, 37-56. [CrossRef]

50. UK Parliament. Convention for the Safeguarding of the Intangible Cultural Heritage: Written Question-HL6360; UK Parliament: London, UK, 2017.

51. Arbol, M.R.D.; Orejas, A. Protection and management of Spanish archaeological-historical landscapes. In The Cultural Landscape \& Heritage Paradox: Protection and Development of the Dutch Archaeological-Historical Landscape and its European Dimension; Bloemers, T., Kars, H., Van Der Valk, A., Wijnen, M., Eds.; Amsterdam University Press: Amsterdam, The Netherlands, 2010; pp. 477-493.

52. Pickard, R. A Comparative Review of Policy for the Protection of the Architectural Heritage of Europe. Int. J. Herit. Stud. 2002, 8, 349-363. [CrossRef]

53. Cruz, L.; Caro, C. The National Plan of Cultural Landscape: 100 Cultural Landscapes in Spain; Spanish Cultural Heritage Institute, Ministry of Education, Culture and Spain: Madrid, Spain, 2016.

54. Afinoguenova, E. Unity, stability, continuity': Heritage and the renovation of Franco's dictatorship in Spain, 1957-1969. Int. J. Herit. Stud. 2010, 16, 417-433. [CrossRef]

55. Núñez, G.; Ruiz, L.G. Little New Under the Sun. Heritage and Public Administration: The Spanish Case. In National Approaches to the Governance of Historical Heritage over Time. A Comparative Report; Fisch, S., Ed.; IOS Press: Amsterdam, The Netherlands, 2008; pp. 146-182. 
56. Amineddoleh, L. The Protection of Abandoned Cultural Heritage in Spain. J. Arts Law Online 2012. [CrossRef]

57. Villarroya, A.; Ateca-Amestoy, V. Spain/1. Historical Perspective: Cultural Policies and Instruments; Compedium of Cultural Policies and Trends: Madrid, Spain, 2015.

58. Agencia Estatal Boletín Oficial del Estado. The Spanish Constitution; Agencia Estatal Boletín Oficial del Estado: Madrid, Spain, 1978. Available online: https://www.boe.es/legislacion/documentos/ConstitucionINGLES.pdf (accessed on 1 March 2019).

59. Capote-Pérez, L.-J. Cultural Heritage and Spanish Private Law. Santander Art Cult. Law Rev. 2018, 2, $237-254$. [CrossRef]

60. Del Estado, J. LEY 16/1985, de 25 de junio, del Patrimonio Histórico Español; BOE: Madrid, Spain, 1985.

61. Viejo-Rose, D. Cultural heritage and memory: Untangling the ties that bind. Cult. Hist. Digit. J. 2015, 4. [CrossRef]

62. Viejo-Rose, D. Reconstructing Heritage in the Aftermath of Civil War: Re-Visioning the Nation and the Implications of International Involvement. J. Interv. State Build. 2013, 7, 125-148. [CrossRef]

63. Swenson, A. The Rise of Heritage: Preserving the Past in France, Germany and England, 1789-1914 (New Studies in European History); Cambridge University Press: Cambridge, UK, 2013.

64. Meskell, L. A Future in Ruins; OUP: New York, NY, USA, 2018.

65. Council of Europe. European Cultural Convention; Council of Europe: Paris, France, 1954. Available online: http://conventions.coe.int/Treaty/EN/Treaties/Html/018.htm (accessed on 1 January 2019).

66. Council of Europe. Convention for the Protection of the Architectural Heritage of Europe; Council of Europe: Granada, Spain, 1985. Available online: https://rm.coe.int/CoERMPublicCommonSearchServices/ DisplayDCTMContent?documentId=090000168007a087 (accessed on 1 January 2019).

(C) 2019 by the authors. Licensee MDPI, Basel, Switzerland. This article is an open access article distributed under the terms and conditions of the Creative Commons Attribution (CC BY) license (http://creativecommons.org/licenses/by/4.0/). 